\title{
Art paintings accessible to the blind
}

Aksinja Kermauner*

aksinja.kermauner@gmail.com

https://orcid.org/0000-0003-0731-3002 https://doi.org/10.31192/np.19.3.9

UDK / UDC: 75:316.344.6-056.262

Pregledni članak/ Review Primljeno / Received:

5. veljače 2021. / Feb 5, 2021

Prihvaćeno / Accepted:

19. svibnja 2021. / May 19, 2021

The purpose of the article is to explore in what ways visual arts can be brought closer to blind persons in the postmodern society, in which sight is perceived to be the highest of the senses and in which most information is based on images. The basic methods of presenting a work of art involve the remaining senses, mostly those of hearing and of touch. It is of course not enough just to deliver a factual description of a painting or to transform it into tactile graphics - more complex techniques such as audio-description, method of associations, participating in role-playing, all with the aim of a holistic experience of the work of art, must be sought instead.

Key words: blind persons, painting, sense of touch, sense of hearing, tactile picture.

\section{Introduction}

Fully sighted people, believe our experience of the world is the only valid, true and complete one. If we parallel the way we sense the world to the way a blind person, who lacks a sense as important as sight, does, we tend to comprehend the blind person's world as a rather curtailed version of the world of the fully sighted. Through the paradigm of this contraction of the world the blind persons are perceived as imperfect, disabled. Since we live in a world created to suit the fully sighted, the tendency to bring the world of the blind persons closer to the world of the fully sighted seems completely reasonable. What about access to visual arts, especially to painting, for the blind persons?

In Slovenia, there are about 4000 people registered as blind or partially sighted persons, among which 2000 are totally blind ${ }^{1}$ (The Union of Associa-

\footnotetext{
* Aksinja Kermauner, PhD, Assist. Prof., Univerza na Primorskem, Pedagoška fakulteta, Cankarjeva 5, SI-6000 Koper, Slovenija.

1 The Union of Associations of Blind and Visually Impaired of Slovenia.
} 
tions of Blind and Visually Impaired of Slovenia). In countries with developed healthcare systems, the incidence of blindness is 1 to 1.5 per million, with Slovenia in the European average (1.15 per million).

Blindness in Slovenia is, in line with the European definition, defined as follows: residual vision between 0 and $4.9 \%$ or narrowed visual field (under $10^{\circ}$ in the better eye). From the pedagogical aspect, these definitions are more complex and successful use of residual vision is taken into account. There are many blind people with residual vision or at least some perception of light (practical blindness).

\section{Human senses}

Without exception, our senses determine our relation to the world. The body is not just the focal point in the central perspective and the senses not just passive recipients of information. Pallasmaa ${ }^{2}$ states that our existence in the world is a sensing and embodied way of being. According to Pecelt in Gžegoževska, ${ }^{3}$ each experience has the nature of the system of those sensory areas that are characteristic of a fully sighted person. All the senses form the basis for the creation of the content of consciousness. In each sensory experience, temporal and spatial relations are present, for which the totality of the 'self' represents the basis. Pallasmaa also asserts that we experience the world with the whole bodily existence. The world organizes and articulates itself with the body in the centre. Even if the body lacks one of the senses, the human is able to create a credible notion of the world she or he is surrounded by. Von Glasersfeld ${ }^{4}$ speaks about viability: if biological and cognitive configuration of the sensory space make the survival of an organism possible, its world is viable. The findings of neurophysiology and modern cognitive philosophy indicate that every experience of the world that is viable is also complete ${ }^{5}$. Every organism constructs its own cognitive world, which depends on its biological state. Hence the presumption that a world created with a certain configuration of senses is the right or complete one, while another is not, is rather questionable. Why should the world of dolphins, bats, insects, or birds be more real, righter than the world perceived by people? All the worlds are the right ones, if their creators manage to survive.

\footnotetext{
${ }^{2}$ Juhani PALLASMAA, Oči kože: arhitektura in čuti [The eyes of the Skin: Architecture and the Senses], Ljubljana, Studia humanitatis, zbirka Varia, 2007.

${ }^{3}$ Marija GŽEGOŽEVSKA, Psihologija slepih [Psychology of the Blind], 1. tom, samo za internu upotrebu, Naučno pedagoško društvo, 1971.

${ }^{4}$ Ernst von GLASERSFELD, Adaptation and Viability, American Psychologist, 35 (1980) 11, 970 974.

${ }^{5}$ Francisco J. VARELA, Evan THOMPSON, Eleanor ROSCH, The Embodied Mind: Cognitive Science and Human Experience, Cambridge MA, MIT Press, 1991.
} 


\section{Sight}

The eye (Latin oculus, Greek ofthalmos) receives as much as $83 \%$ of all information (the ear $11 \%$; the remaining senses - touch, smell, taste $-6 \%$ ), while it only takes $1 / 357$ of the surface of the human body. It is so sensitive that it reacts to a single quantum of light. Unlike sounds and smells, what can be seen, can be touched ${ }^{6}$.

We, people, are beings of eyes. It is predominantly sight that determines what we know about the world. We think in pictures. We are the only inhabitants of the Earth who can create pictures and recognize features in them. Because we are trained to do so, we are most often able to identify objects faster using sight than using touch or hearing. We look at many things without holding them. There are, however, certain characteristics that cannot be revealed by sight. If we see a stone, sight tells us nothing about its weight or about its warmth. On the other hand, we would probably not be able to determine the colour by touching, although Chazzari ${ }^{7}$ states certain individuals can tell the colour of an object from the warmth it radiates.

\section{Sensing with the Blind - Surrogate Senses}

Through carefully planned and systematic exercise with the blind, the functioning of the remaining senses improves to the point they take over the function of sight. This is a partial compensation for the absence of information a blind person would otherwise receive through the visual channel. For a blind person, touch is the most important way of establishing contact with the real world. Ontologically, touch is actually the oldest sense and other senses, including sight, are extensions of touch. They are specialisations of skin tissue and all forms of sensing are adapted forms of touch.

\subsection{The sense of touch}

Because of their visual impairment, blind people are forced to discover the world with the help of other senses. In this way other senses try to compensate for the lack of sight. Beside the sense of hearing, it is tactile kinaesthetic senses that are the most developed. With these senses, a blind person can perceive the world and create certain notions about it. This is the way of getting an image

\footnotetext{
${ }^{6}$ Aksinja KERMAUNER, Fenomenologija samogenerirane slepote [Phenomenology of selfgenerated blindness], Doctoral dissertation, University of Ljubljana, Faculty of Education, 2010.

7 Suzy CHIAZZARI, Barve [Complete Book of Color], Ljubljana, Slovenska knjiga, 2000.
} 
of an object. For a blind person, touch is the only way to establish a connection with the real world.

We use several body parts, especially hands, for identifying different objects. Fingertips play the biggest role here. A blind person can enhance the sensitivity of the index finger up to $50 \%$ compared to a sighted person, which is a consequence of intensive training of senses. ${ }^{8}$

\subsection{Sense exercises}

Blind people do not possess higher sensitivity of their sense organs, as some people wrongly suppose. A sense organ, including residual sight, if there is any, must be trained constantly. Therefore, regular exercises for the sense organs (sight, hearing, smell, taste and touch) of blind people are required.

\section{Touch exercises}

Touch exercises are systematic exercises for enhancing tactile perception (e.g. development of fingertip sensitivity); exercises for recognizing different materials, weights, structures; perception with other parts of the body; exercises with indirect tactile perception. ${ }^{9}$ Touch exercises are extremely important in the earliest periods of human life. We encourage babies to start using their fingers..$^{10}$ Meissner's corpuscles play an important role in touching and later on in reading the Braille. If we want that each cell sends a stimulus to the brain, tactile information should be at least $1 \mathrm{~mm}$ apart (tactile threshold). As previously noted, in order to perceive objects, we use several parts of our body, especially hands. Fingertips are very important. According to Fieandt in Zovko, ${ }^{11}$ our fingertips are able to transfer perceptions extremely well, sometimes even better than the eye. By practicing certain exercises, we can vastly improve our sense of touch. With touch, however, we cannot perceive quite everything; the problem may be a motion. For a full-sighted viewer, the image of an arrow in the air means an image of a moving arrow. The touch lacks a dimension of dynamics; even if the arrow were depicted tactilely, it would be a dormant arrow. The Discobolus of Miron is just a static statue for the person who is blind. ${ }^{12}$

\footnotetext{
${ }^{8}$ Gojko ZOVKO, Peripatologija [Peripathology], Ljubljana, Zavod Republike Slovenije za šolstvo, 1995.

9 Roman BRVAR, Geografija nekoliko drugače [Geography in a different way], Ljubljana, Zavod Republike Slovenije za šolstvo, 2000.

${ }^{10}$ Patricia SONKSEN, Blanche STIFF, Show me what my friends can see, The Developmental Guide for Babies with Several Impaired Sights and their Professional Advisers, London, Institute of Child Health, 2001.

${ }^{11}$ Zovko, Peripatologija...

${ }^{12}$ Thomas D. CUTSFORTH, The Blind in School and Society. A Psyhological Study, New York, American Foundation for the Blind, 1951.
} 
Even the experiences of sighted people, who perceive that with distance the object seemingly decreases, and the lines of otherwise rectangular objects are perspective distorted, are unknown to the person who is congenitally blind..$^{13}$

It is also impossible to touch oversized or undersized, sensitive and dangerous things, but Lowenfeld ${ }^{14}$ is convinced that the blind can nevertheless have a very clear idea of these objects. If, of course, we take into account the difference between sight and type, or follow the laws of the preparation of tactile representations and add other senses, we can bring a two-dimensional work of art quite close to the person with blindness.

While hearing also plays an important role in spatial perception, spatial features of hearing are based on associations connected with haptic perception. This is why, according to Heller ${ }^{15}$, touch is the only real sense of spatial perception for the blind. With haptic-kinaesthetic senses, the blind perceive space and thus receive information about the world ${ }^{16}$. But touch is a proximal sense, which means there are considerable limitations when it is used to gather information about the world.

However, hearing also plays a significant role in learning about the world. With the sense of hearing, the blind can determine the various properties of the object that emits sound; where does the sound come from; what are the spatial and temporal relationships.

In the perception of works of art, the message value of sound is perhaps even more important for the person who is blind - a sound description or audio description of a work of art, a theatrical performance, a film.

Hearing notions enable the blind to learn how to speak. Bürklen ${ }^{17}$ says that the blind persons speak in the language of the fully sighted and they also think in the language of the fully sighted. Thus, they also use the words for colours.

\subsection{Colour}

Psychophysiology teaches that a colour is just a sensation on the retina when photons excite the receptor cells (the cones). These react with a chemical reaction that transforms stimuli into impulses, which then travel through the optic nerve and certain other structures into the visual centre in the temporal lobe. While the processes in the cortex have not been completely explored yet, it is

\footnotetext{
${ }^{13}$ Annick VANLIERDE, Marie-Chantal WANET-DEFALQUE, The Role of Visual Experience in Mental Imagery, Journal of Visual Impairment \& Blindness, 99 (2005) 3, 165-178.

${ }^{14}$ Berthold LOWENFELD, The Changing Status of the Blind: from Separation to Integration, Springfield, Charles C. Thomas Publisher, 1975.

${ }^{15}$ Theodore HELLER, Študije $k$ psihologiji slepih [Studien in der Psychologie der Blinden], Würzburg, Edition Bentheim, 1989.

${ }^{16}$ Brvar, Geografija nekoliko drugače...

${ }^{17}$ Karl BÜRKLEN, Psihologija slepih [Blinden-Psychologie], Leipzig, Verlag von Johann Ambrosius Barth, 1924.
} 
clear that all the feelings we experience through our sense organs have their origin in the brain. For a blind person, colour is merely an abstract concept, yet a lot of congenitally blind people know the colours by name, they form associations when colours are mentioned, they associate various objects and concepts with colours (the Sun is yellow, grass is green; black represents sadness, etc.), they nurture affection for certain colours, and in a way imagine the colours through sensory interaction.

Synaesthesia is another useful tool for imagining a certain colour. According to Bürklen, ${ }^{18}$ 'photism' is the stimulus we get with the help of another sense and is manifested in the visual centre (a certain sound appears to be, e.g., red; likewise, the blind can perceive smells and tastes as coloured). Colours can also be associated with various textures. In 2004, Kermauner carried out a study among Slovenian primary school pupils in order to invent a way of presenting warm and cool colours to the totally blind. Through the study, she wished to discover which materials they perceive as warm and which as cool. The results revealed the examinees found rough materials to be warm and smooth materials cool. On the basis of these findings, Kermauner conceived the first Slovenian tactile picture book Snežna roža (Snow Flower, Figure 1), which builds on the cool-warm contrast. This means she associate warm colours with the materials that appear warm to the touch and cool colours with the materials that feel cool to the touch. ${ }^{19}$

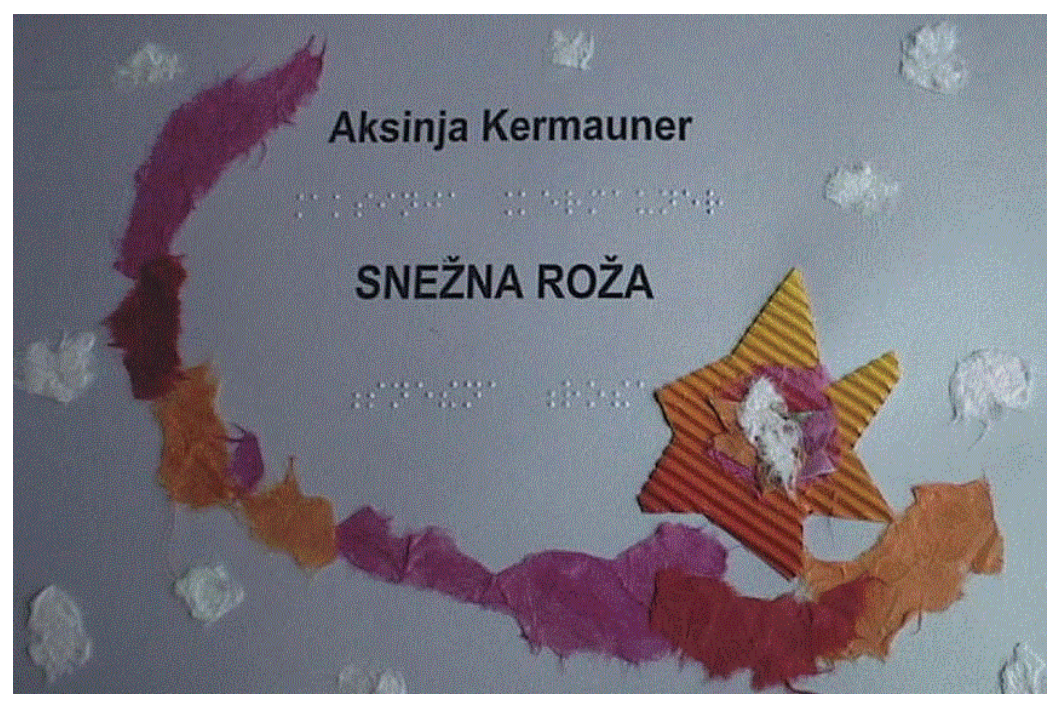

Figure 1: Snow Flower by Aksinja Kermauner (Own source)

\footnotetext{
${ }^{18}$ Bürklen, Psihologija slepih...

${ }^{19}$ Aksinja KERMAUNER, Tipna slikanica za slepe [Tactile picture book for blind], Bachelor's thesis, University of Ljubljana, Faculty of Education, 2004.
} 


\section{Visual Arts and the Blind}

Works of fine arts are visible materialisations. ${ }^{20}$ They are not copies or replicas of objects, but rather their equivalent in the selected medium: ideas, notions about the world. A visual work of art affects the viewers with the visual language, which is a system of visual elements. Viewers perceive them by sight, the main sense pertaining fine arts.

In the past, there was a lot of discussion on whether touch can replace sight to the extent that the blind would also have access to two-dimensional visual works of art. There was a search for an analogy between sight and touch, between the eye and the touching hand, between the fovea and the tips of forefingers. Descartes and Willey understood sight as touching at a distance with added colours, while touch is sight from which colours have been taken away and the perception of various textures added. ${ }^{21}$ This erroneous assumption caused a lot of problems, especially in the pedagogical sense. Concerning their functioning, there are enormous structural differences between the two senses.

Table 1: Basic differences between sense of sight and touch

\begin{tabular}{|l|l|}
\hline Sight & Touch \\
\hline Distal & Proximal \\
\hline Synthetic & Analytic \\
\hline Colour & Texture \\
\hline Tone & Roughness, smoothness \\
\hline The whole & Detail \\
\hline Swift look & Longer exploring time \\
\hline Immediate & Sequential \\
\hline Eye movement & Movement of hands, fingers \\
\hline Field without boundaries & Limited field of immediate touch ${ }^{22}$ \\
\hline
\end{tabular}

The discussion of the differences between sight and touch has become known as the Molyneux's problem - the philosopher asked Locke a hypothetical question in their correspondence: A congenitally blind man has learned to differentiate between a metal cube and a sphere. Will this man, after the operation of cataract has restored his sight, be able to tell which is the cube and which is the sphere just by looking at them, without the aid of touch? ${ }^{23}$

\footnotetext{
${ }^{20}$ Tomaž GORJUP, Likovne zakonitosti in aktivnosti delovne terapije [Art laws and activities of occupational therapy], Ljubljana, Državna založba Slovenije, 1999, 19.

${ }^{21}$ Mark PATERSON, The Senses of Touch: Haptics, Effects, and Technologies, Oxford, Berg, 2007.

${ }^{22}$ Philippe CLAUDET, Maintenant je sais ce que blanc veut dire [Now I know what white means], Dijon, Les Droits Que Révent, collection Corpus Tactilis, 2009.

${ }^{23}$ Paterson, The Senses of Touch: Haptics, Effects, and Technologies...
} 
In his famous letter on the blind for the use of those who see Diderot quotes Voltaire: Cheselden's blind patient, who was suddenly able to see for the first time, needed some amount of time before he was able to orient himself in the world. He did not understand, among other things, the distance between an object and the picture of the object on the retina. He believed »the object touched the eye «. ${ }^{24}$ With vision, he was neither able to recognize objects nor to understand their relative position in space. The greatest problem for him represented perspective. When observing paintings, he had to touch the surface with his fingers to discover, with surprise, that the image is two-dimensional. Voltaire reports that upon this the man asked him which of the senses had betrayed him - sight or touch.

With touch, it is not possible to feel everything, e.g., the representation of movement in a picture. For a fully sighted person, the image of an arrow in the air means an image of the arrow in movement. Touch lacks the dynamic dimension; even if the arrow was represented in a tactile way, this would be an arrow standing still. For a touching person, Disc Thrower is just a static statue. ${ }^{25}$ Also the experiences of the fully sighted that the size of an object apparently decreases with distance and that perspective deforms lines of otherwise rectangular objects, are unknown to the congenitally blind.$^{26}$ Likewise, it is not possible to palpate excessively large or extremely small, delicate or dangerous things, but Lowenfeld ${ }^{27}$ nevertheless believes that the blind can still have a very clear notion of these objects. Considering the difference between sight and touch or following the rules of preparing tactile presentations with the remaining senses added, a two-dimensional work of art can be brought much closer to a blind person.

Motluk $^{28}$ writes about the brain research of the adult congenitally blind painter Esref Armagan from Turkey, who accurately depicts houses, roads, waterfalls with all the perspective abbreviations that can only be perceived by sight; as well as clouds, butterflies, i.e. objects that are not accessible to tactile perception. Imaging his brain with functional magnetic resonance imaging (fMRI) while imaging or thinking about the painting shows a picture of the brain of a seeing person. His visual center is as active during these actions as the centre of sighted person.

\footnotetext{
${ }^{24}$ Denis DIDEROT, Pismo o slepih v rabo tistim, ki vidijo [A letter about the blind for use by those who see], in: Miran BOŽOVIČ (ed.), D'Alembertove sanje in drugi filozofski spisi [D'Alembert's Dreams and Other Philosophical Writings], Ljubljana, Založba ZRC, ZRC SAZU, 2010, 133193.

${ }^{25}$ Thomas D. CUTSFORTH, The Blind in School and Society, A Psyhological Study, New York, American Foundation for the Blind, 1951.

${ }^{26}$ Vanlierde, Wanet-Defalque, The Role of Visual Experience in Mental Imagery..., 165-178.

${ }^{27}$ Lowenfeld, The Changing Status of the Blind: from Separation to Integration...

${ }^{28}$ Alison MOTLUK, The art of seeing without sight. New Scientist (2005), http://motluk.com/ stories/ns.art.of.seeing.without.sight.html (10.01.2021).
} 
Even though many blind people do not have this unusual ability, we will certainly not object to the requirement that blind and partially sighted persons also express themselves in the field of art and enjoy the greatest possible pleasure when in contact with art.

\section{Adaptations of a Painting: Tactile Pictures, Sound Pictures, Living Pictures}

A fully sighted observer is at first affected by a painting on a completely unconscious level. Reason, which analyses data, reads the story, etc., only gets involved later. A similar path, I believe - some sort of a hermeneutic algorithm - should be taken with the blind and partially sighted. ${ }^{29}$ First, an efficient contact should be established with the work of art, using poetic language, associations, music, sounds, movement, participation - only at a later stage should we describe it verbally (pre-iconographic description, iconographic analysis, iconological analysis) and place the work of art in a historical and social context.

\section{Tactile Pictures}

In principle, plastic art does not represent a problem for the blind as long as they can touch it and as long as it is of adequate size - neither too small nor too big - and made of safe material. But how can two-dimensional works of art be transformed into tactile form? If a drawing or a painting is simple, it can be represented in relief. ${ }^{30}$

Based on the realization that there is no manual for the teaching of fine arts for the blind and visually impaired students, Raschini ${ }^{31}$ has created a useful teaching book for both blind, visually impaired and their sighted classmates. In this way, it corresponds to the principle of an inclusive school, in which a blind and sighted student sit in the same bench. She was guided by the idea that if currently blind students cannot see a similar experience with sighted people when visiting a museum, we can provide them with this experience of learning about fine arts in school.

She selected the 10 most important painters from different periods of contemporary art and 11 of their paintings - portraits or self-portraits. She used a relief pencil (embossing needle) to create embossed images, which has a metal

\footnotetext{
${ }^{29}$ Jožef MUHOVIČ, S slikarstvom na štiri oči [A face-to-face meeting with painting], Ljubljana, Raziskovalni inštitut Akademije za likovno umetnost in oblikovanje, 2012, 8.

${ }^{30}$ Art Beyond Sight, A Resource Guide to Art, Creativity and Visual Impairment, Art Education for the Blind (AEB) and AFB Press of the American Foundation for the Blind, 2003, 271-282.

${ }^{31}$ Ilaria RASCHINI, Ko gledamo s prsti in dlanmi: Umetnost skozi dotik [When we look with our fingers and palms: Art through touch], Master's thesis, University of Primorska, Faculty of Education, 2014.
} 
ball instead of a writing tip with ink. Short biographies of selected artists and their paintings are written in black and in Braille, printed on transparent foil, and below it is a plain white sheet on which the same text is printed in enlarged black, which is also suitable for visually impaired readers and all others, who have no vision problems. All A 4 format sheets are collected in a ring folder, from which the reader can easily take a picture from the folder, if necessary, to view it closely (Figure 2).

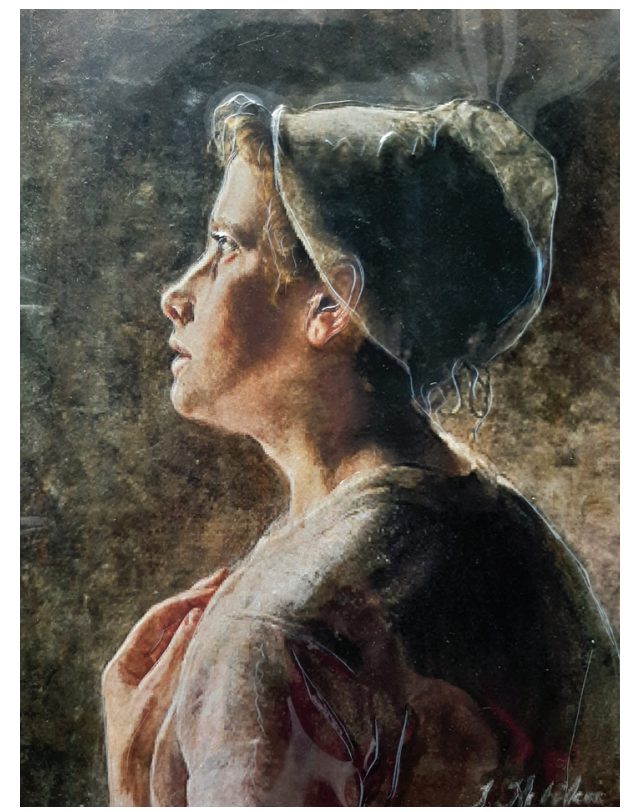

Figure 2: An example from a handbook for learning modern arts for blind and visually impaired students (Own source)

We also have different collages, inflatable and contour colours, certain types of print, the Braille and computer tactile graphics, etc. at our disposal. The content of the picture must be adapted, i.e., abstracted and generalized: only the most important information remains - to avoid the picture being unclear; but also, the blind person's tactile threshold must be regarded. Lines of different widths can be used, as well as different surface pattern.

With more complex pictures, other methods can be considered. The first such method is to produce progressive presentations - the foreground on one tactile picture, the background on the other; the third is a fusion of both. Another method is to create an extremely simplified version of the whole composition in order to allow the blind to comprehend, by touch, the relations between the parts of the picture. After that, details are presented on individual enlarged parts of the tactile image. The information in these presentations is again reduced to basic tactile data; this is why it is (intentionally) impoverished. 


\section{Some rules for creating tactile pictures}

Size: the dimensions of tactile pictures should be adjusted to the hands of a blind person. A tactile picture should not be larger than the A4 size.

Generalisation: a tactile picture should be generalised to the extent that its motifs can be still well recognised by touch.

Material: the material should be associated with the real materials of the objects represented on the tactile picture, or it should at least support some essential characteristics (cold materials - cold colours).

Security: The materials and the making should be safe.

In a very useful book Art Beyond Sight Joel Snyder ${ }^{32}$, one of the leading figures in the area of audio-description for theatre, television, film, galleries and museums, offers some examples of describing classical paintings. The purpose of describing is an in-depth artistic analysis of the work of art, including the culture of the era, data on the author and the motif and explanation of the painting style.

Radio producer Lou Giansante ${ }^{33}$ demonstrated a way of presenting a work of art or an artistic element through sound. In his first sound description, he tried to create the illusion of space in the blind with a voice going away or coming closer, thus causing a similar feeling as perspective is for the fully sighted. In his second sound description, he tried to explain surrealism with the help of an actual work of art - Salvatore Dali's The Persistence of Memory. For this purpose, he used music, different sounds, noises, and associations (the sound of the sea, baby crying, and door creaking).

Works of art can also be presented through drama or as a living picture. To illustrate Da Vinci's Last Supper, the 12 apostles and Christ were sat around a table and the blind were invited to participate in the supper or to just touch. Bonin ${ }^{34}$ made also a tactile diagram of Last Supper (Figure 3), audio description, tactile picture, and model (Figure 4).

King ${ }^{35}$ describes how to stage Da Vinci's Lady with an Ermine. A girl is dressed in a corresponding costume and sat in the same position as the lady in the picture. Two assistants hold a wooden painting frame in front of the girl so the viewer can place the scene. In addition, the painting can be also

\footnotetext{
${ }^{32}$ Joel SNYDER, Verbal description: The visual made verbal, in: Art Beyond Sight, A Resource Guide to Art, Creativity and Visual Impairment, Art Education for the Blind (AEB) and AFB Press of the American Foundation for the Blind, 2003, 224-247.

${ }^{33}$ Lou GIANSANTE, How Sound can Help Convey Visual Concepts, in: Art Beyond Sight, A Resource Guide to Art, Creativity and Visual Impairment, Art Education for the Blind (AEB) and AFB Press of the American Foundation for the Blind, 2003, 256-257.

${ }^{34}$ Boštjan BONIN, Veččutno zaznavanje da Vincijeve Zadnje večerje, prilagojene slepim in slabovidnim osebam [Multisensory perception of da Vinci's Last Supper, adapted for blind and partially sighted persons], Master's thesis, University of Primorska, Faculty of Education, 2015.

${ }^{35}$ Ermyn KING, Drama, movement, sound, and the visual arts, in: Art Beyond Sight, A Resource Guide to Art, Creativity and Visual Impairment, Art Education for the Blind (AEB) and AFB Press of the American Foundation for the Blind, 2003, 258-263.
} 


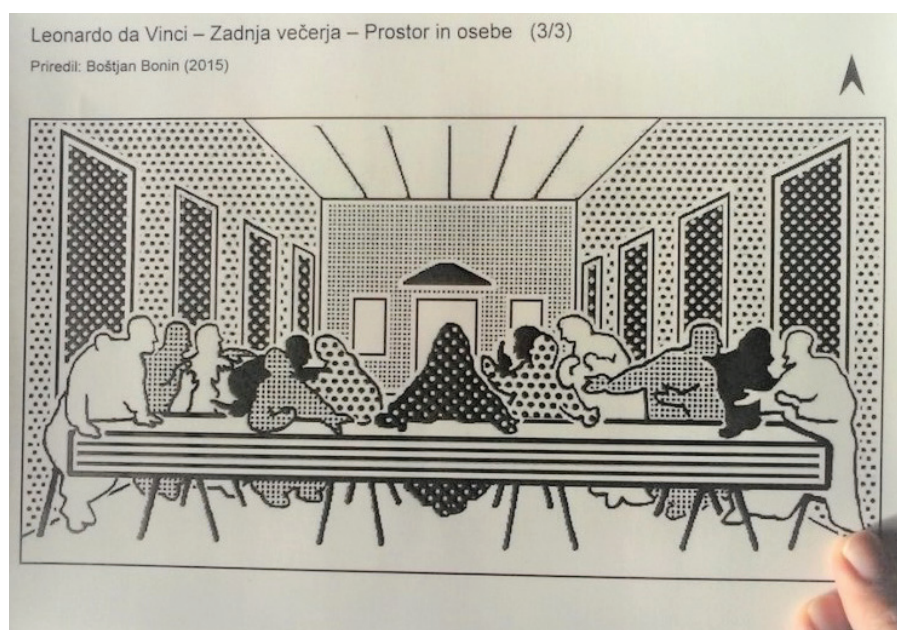

Figure 3: The tactile diagram of Last Supper by Boštjan Bonin (Source: Tactile diagram of Last Supper, Boštjan Bonin, Master's thesis, University of Primorska, Faculty of Education, 2015)

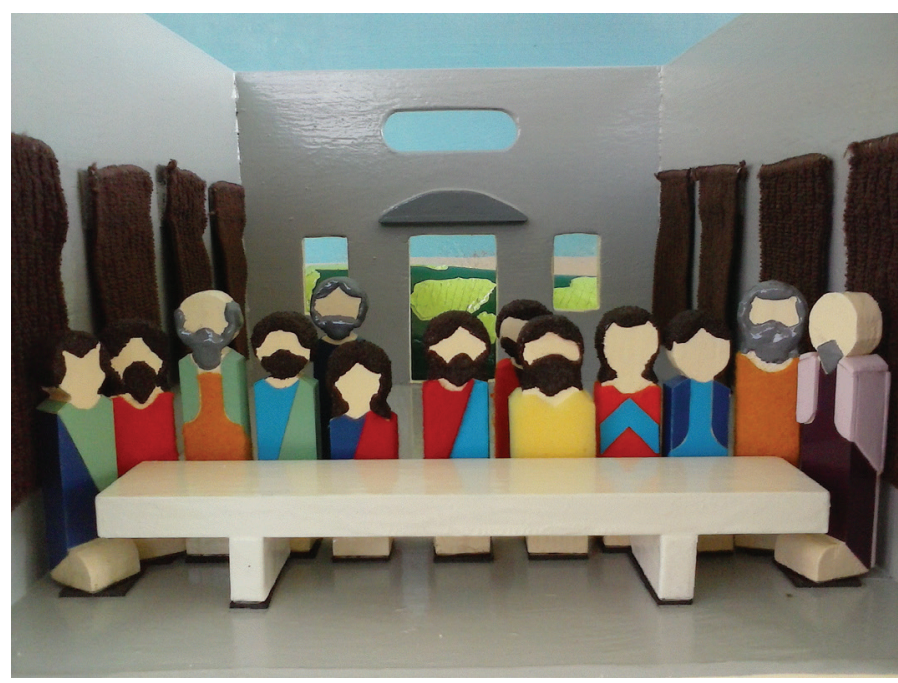

Figure 4: The simplify Last Supper by Boštjan Bonin (Source: Model of Last Supper, Boštjan Bonin, Master's thesis, University of Primorska, Faculty of Education, 2015)

described - the mutual effects of sound and movement provide a kinaesthetic, multisensory and emotional experience of the work of art.

In the Maribor Art Gallery (Slovenia), a girl was dressed like the girl in the painting A girl with an orange by Ivan Kos (Figure 5). Visitors could touch the figure and smell and touch the orange. 


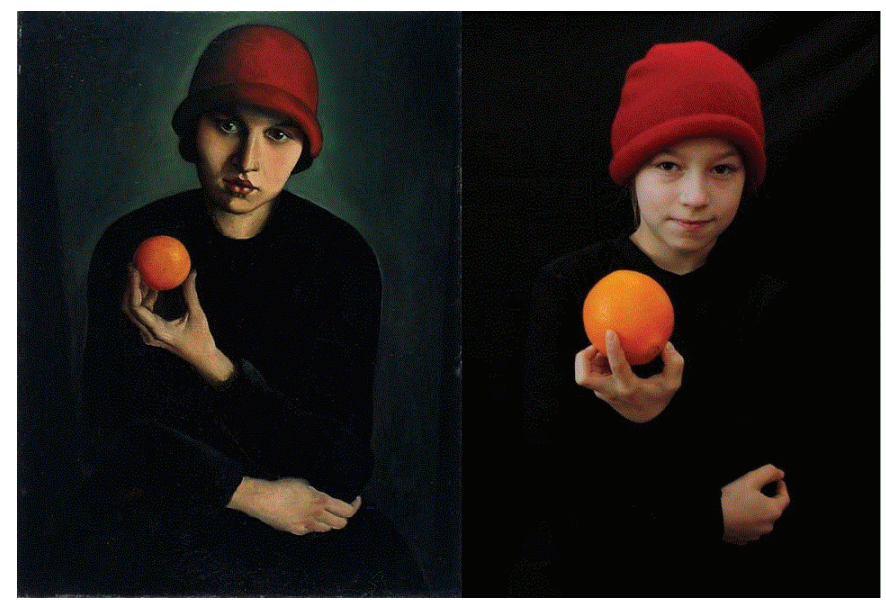

Figure 5: A girl with an orange, 1927, painting by Ivan Kos (left); and the living picture (right) (Source: Maribor Art Gallery, curator Brigita Strnad, 2014)

\section{Conclusions}

Several galleries and museums in Slovenia offer multisensory experiences for the blind and partially sighted. The Slovene Ethnographic Museum is currently leading the project Access of vulnerable groups to cultural heritage. The National Gallery in Ljubljana is preparing special exhibitions of the most famous paintings from Slovene history, where it will be possible to touch the work of art as a tactile picture, and to observe it closely as a minimised reproduction in vivid colours. There will be an audio description of the painting, as well as a »living picture « - a person, dressed as the character from the painting, who will be able to offer visitors information about the creation of the painting, the motif, the technique, the painter, etc.

Our aim is to use the combination of all these methods to bring art, especially painting, closer to the blind and partially sighted. Practice has shown that the approaches suitable for the blind and partially sighted can be valuable also for the fully sighted, who can thus experience a work of art in a multisensory way. 


\section{Aksinja Kermauner* \\ Umjetničke slike dostupne slijepima \\ Sažetak}

Svrha članka je istražiti na koji se način vizualne umjetnosti mogu približiti slijepim osobama u postmodernom društvu, u kojem se vid smatra najvećim od osjetila i u kojem se većina informacija temelji na slikama. Osnovne metode predstavljanja umjetničkog djela uključuju preostala osjetila, uglavnom ona sluha i dodira. Nije naravno dostatno pružiti samo činjenični opis slike ili je transformirati u taktilnu grafiku - umjesto toga mora se tražiti složenije tehnike, kao što su audio-opis, metoda asocijacija, sudjelovanje u igranju uloga, a sve radi holističkog iskustva umjetničkog djela.

Ključne riječi: osjet dodira, slijepe osobe, slikanje, sluh, taktilna slika.

(na hrv. prev. Izidora Kazić)

\footnotetext{
* Doc. dr. sc. Aksinja Kermauner, Univerza na Primorskem, Pedagoška fakulteta, Cankarjeva 5, SL-6000 Koper, Slovenija; e-mail: aksinja.kermauner@gmail.com.
} 